\title{
FACTORYLESS GOODS PRODUCERS IN THE US*
}

\author{
by \\ Andrew B. Bernard \\ Tuck School of Business at Dartmouth \\ Teresa C. Fort \\ Tuck School of Business at Dartmouth
}

CES 13-46 September, 2013

The research program of the Center for Economic Studies (CES) produces a wide range of economic analyses to improve the statistical programs of the U.S. Census Bureau. Many of these analyses take the form of CES research papers. The papers have not undergone the review accorded Census Bureau publications and no endorsement should be inferred. Any opinions and conclusions expressed herein are those of the author(s) and do not necessarily represent the views of the U.S. Census Bureau. All results have been reviewed to ensure that no confidential information is disclosed. Republication in whole or part must be cleared with the authors.

To obtain information about the series, see www.census.gov/ces or contact Fariha Kamal, Editor, Discussion Papers, U.S. Census Bureau, Center for Economic Studies 2K132B, 4600 Silver Hill Road, Washington, DC 20233, CES.Papers.List@census.gov.

\footnotetext{
* This paper was prepared for the conference on The FactoryFree Economy: what next for the $21^{\text {st }}$ century? held in Paris, June 17-19, 2013. The research in this paper was conducted while the authors were Special Sworn Status researchers of the US Census Bureau at the Boston Research Data Center and the Center for Economic Studies. Any opinions and conclusions expressed herein are those of the authors and do not necessarily reflect the views of the Census Bureau, the NBER, or any other institution to which the authors are affiliated. All results have been reviewed to ensure that no confidential information is disclosed.
} 


\begin{abstract}
This paper documents the extent and characteristics of plants and firms in the US that are outside the manufacturing sector according to official government statistics but nonetheless are heavily involved in activities related to the production of manufactured goods. Using new data on establishment activities in the Census of Wholesale Trade conducted by the US Bureau of the Census in 2002 and 2007, this paper provides evidence on so-called "factoryless goods producers" (FGPs) in the US economy. FGPs are formally in the wholesale sector but, unlike traditional wholesale establishments, FGPs design the goods they sell and coordinate the production activities. This paper documents the extent of FGPs in the wholesale sector and how they differ from traditional wholesalers in terms of their employment, wages, productivity and output. Reclassifying FGP establishments to the manufacturing sector using our definition would have shifted at least 595,000 workers to as many as $1,311,000$ workers from wholesale to manufacturing sectors in 2002 and at least 431,000 workers to as many as 1,934,000 workers in 2007.
\end{abstract}

JEL Classification: D22,F61,L23,L24,L81 


\section{Introduction}

The global economy has undergone a series of rapid, connected transformations in recent years that are changing the way we think about firms and sectors and that have potentially large consequences for future policy, productivity and prosperity. International trade in goods has surged with the ratio of trade to GDP increasing for almost all exporter-importer country pairs. This substantial increase in trade has been accompanied by the rise of the importance of global value networks and the fragmentation of production activities across national borders even within narrowly-defined goods categories. At the same time, there has been renewed interest in the fragmentation of production activities across the boundaries of the firm and its links to the increases in trade and offshoring of production. The different activities of the value chain for a product can be performed by one or more establishments of a single firm, or can involve many different firms. In both cases, the activities can be performed in different locations within and across country borders. However, to date, almost all analyses of these trends and their consequences for output, employment or productivity, either aggregate or firm-level, have focused on establishments and firms in the manufacturing sector and their decisions to outsource or offshore.

In this paper we consider an extreme form of the fragmentation of production activities where the establishment is outside the manufacturing sector according to official government statistics but nonetheless is heavily involved in activities related to the production of manufactured goods. These establishments are found in the wholesale sector and are formally known as "factoryless-goods producers" (FGPs). Traditional wholesalers are primarily, or exclusively, involved in intermediating goods between producers and retailers/consumers. Factoryless goods producers, in contrast, design the goods they sell and coordinate the production activities, either at the establishment itself or through the purchase of contract manufacturing services. In other words, FGPs are manufacturinglike in that they perform many of the tasks and activities found in manufacturing establishments themselves.

There are many ways to classify the activities or tasks needed to take a product from an initial concept through production until its delivery to the final customer. Pre-production activities can include development of the initial idea or conceptualization, $\mathrm{R} \& \mathrm{D}$, product design and engineering as well as development of specifications for production. Production itself involves transformation and assembly of inputs and coordination of the various production stages. Post-production tasks might cover the determination of prices and quantities, marketing and branding, logistics and the ultimate sale of the good to final customers ${ }^{1}$

Traditionally, these activities were undertaken by the same firm in one location. Today, firms may perform different parts of each production stage, as well as the stages themselves, in different

\footnotetext{
${ }^{1}$ Our focus is on tasks related to production of the goods themselves. We do not address the issue of services provided to the customer by the firm. This growing activity is discussed in Crozet and Milet (2013)
} 
Figure 1: From Idea to Customer

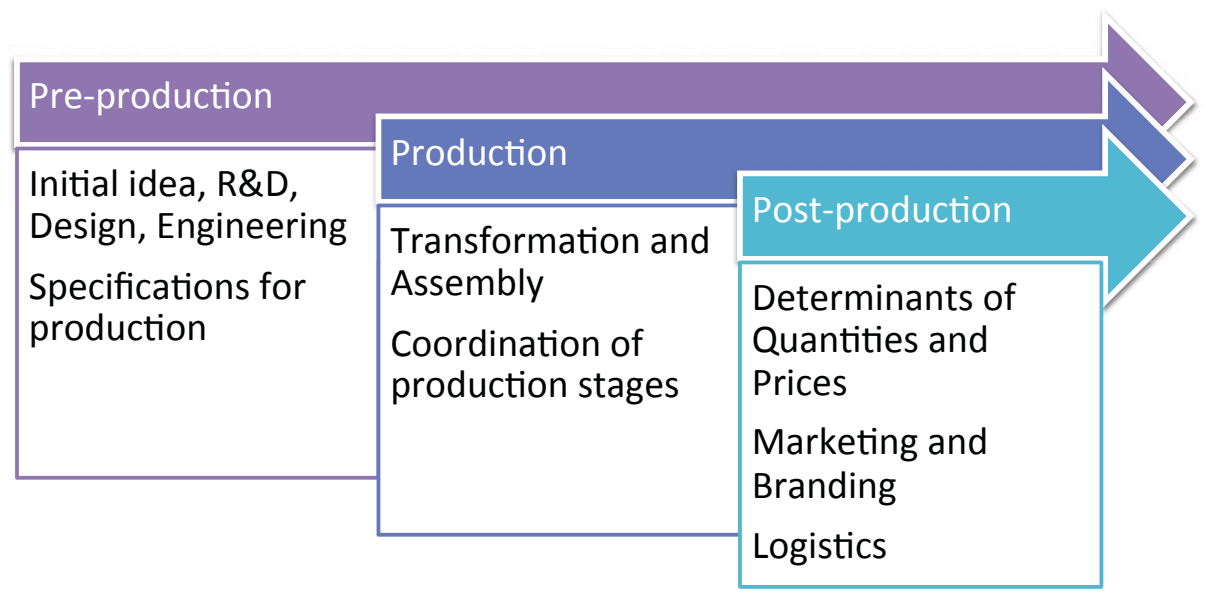

domestic and foreign locations. When the activities are separated in space, firms can also decide whether they should outsource them to others. We define a factoryless goods producer as an establishment that is outside of the manufacturing sector but performs pre-production activities such as design and engineering itself and is involved in production activities either by doing (some of) them at the establishment or through purchases of contract manufacturing services (CMS). ${ }^{2}$ CMS purchases entail an arrangement in which the FGP provides design and production criteria to a manufacturer who performs the physical transformation activities, generally on materials or inputs specified by the FGP.

FGPs are not hard to find. Perhaps the best-known example of a factoryless goods producer is Apple Inc. Apple designs, engineers, develops, and sells consumer electronics, software and computers. However, since 2004, Apple has not owned any production lines in the US and the actual production is conducted by other firms, such as Foxconn, in China and elsewhere. While Apple is known for its goods and services and closely controls all aspects of a product, from the idea until the product lands in the hands of the consumer, none of Apple's US establishments would be

\footnotetext{
${ }^{2}$ Our definition differs from that currently under consideration by statistical agencies in the US, see Appendix B
} 
in the manufacturing sector. ${ }^{3}$

The semiconductor industry is well-known to have factoryless goods producers in the form of "fabless" firms. ${ }^{4}$ Mindspeed Technologies, a fabless semiconductor manufacturer in Newport Beach, CA with 500+ employees "designs, develops and sells semiconductor solutions for communications applications in wireline and wireless network infrastructure equipment". ${ }^{5}$ Mindspeed outsources all semiconductor manufacturing to other merchant foundries, such as TSMC, Samsung and others. As with Apple, Mindspeed's establishments would not be in the manufacturing sector.

Perhaps the canonical example of a factoryless goods producer is the British appliance firm, Dyson, best known for its innovative vacuum cleaners. The firm initially designed, engineered and produced household appliances in Wiltshire, England but subsequently chose to offshore and outsource all its production to Malaysia while leaving several hundred research and other employees in the $\mathrm{UK}^{6}$

All three of these FGPs started with production facilities inside the firm in the home country and subsequently shed their production lines and outsourced and offshored production. In addition,these firms retained or expanded other activities including research and development, design, engineering, marketing, and distribution.

Anecdotes aside, however, there is very little systematic evidence on the extent of these types of firms and establishments. In this paper, we use data from the US Census of Wholesale Trade in 2002 and 2007 to systematically document the extent of FGP activities in the wholesale sector in the US and to examine the characteristics of plants and firms that are factoryless goods producers. Statistical agencies in the US and elsewhere are grappling with the problem of how to collect information about the evolving variety of manufacturing-related companies in the economy (OMB (2010)). The US Census Bureau has historically classified many FGP plants in the wholesale trade sector, but beginning in 2017, will move these FGP establishments in to manufacturing. ${ }^{7}$ In addition there may be substantial numbers of non-wholesale FGPs in other sectors such as Business Services. ${ }^{8}$

There are several reasons why distinguishing FGPs from traditional wholesale establishments may be important for economic welfare or policy. First, the mere existence of the FGPs highlights a new type of production function in the global economy involving extreme fragmentation of tasks. Second, the types of workers, and as result jobs and wages, employed by FGPs may differ

\footnotetext{
${ }^{3}$ As of June 2013, Apple has announced but not yet implemented an investment in new manufacturing facilities in the US. For a description of the distribution of value in several of Apple's products, see Kraemer, Linden, and Dedrick (2011).

${ }^{4}$ Bayard, Byrne, and Smith (2013) document the extent and characteristics of FGPs in the US semi-conductor industry.

${ }^{5}$ See the company profile at www.mindspeed.com.

${ }^{6}$ See Financial Times August 23, 2011

${ }^{7}$ Doherty (2013) discusses the expected impact of reclassifying FGPs on US economic statistics including the value of imports and exports and sectoral employment and wages.

${ }^{8}$ Our data do not cover sectors beyond Wholesale Trade and Manufacturing so we are unable to document how many FGPs might exist in other sectors.
} 
significantly from those at integrated manufacturing plants or traditional wholesalers. Third, the relative importance of $\mathrm{R} \& \mathrm{D}$ and innovation is likely more important at FGPs. These potential differences between FGPs and traditional manufacturers and wholesalers introduce the possibility of very different wage, employment, and productivity dynamics if factoryless goods production grows in aggregate activity. We do not address these issues directly, but as a final exercise we attempt to calculate how much employment and output would be shifted from the wholesale sector to the manufacturing sector if FGPs are reclassified. Moving FGP establishments to the manufacturing sector would have shifted at least 595,000 workers to as many as 1,311,000 workers from wholesale to manufacturing sectors in 2002 and at least 431,000 workers to as many as 1,934,000 workers in 2007.

Our research is related to a broader set of questions that asks how production, innovation, knowledge and productivity are related. One perspective is that without production activities located nearby in the long run a firm cannot continue to generate new ideas, improve product quality, innovate its designs and raise productive efficiency. The counterpoint suggests that the advent of dramatic improvements in telecommunication technology, the rise of the internet, and the reduction of transportation and trade costs have combined to allow firms to separate their activities geographically and potentially locate them outside the firm. This perspective suggests firms will thrive if they can take advantage of comparative advantage and relative cost differences in the performance of the tasks involved in the creation, production, distribution and marketing of a product. Co-location of these tasks may not be necessary and might be more costly.

We provide a first step in developing an understanding of these complex processes by documenting the extent to which plants are engaged in different activities in the production value chain. Our focus is on establishments that are currently characterized by statistical authorities as performing wholesale trade, i.e. those that are thought to be outside manufacturing. We are motivated by the idea that the rapid decline in manufacturing employment in the US in recent years has been accompanied at least in part by a rise in employment in manufacturing-related activities in other sectors. ${ }^{9}$

\section{Relation to existing work}

This paper contributes to a growing empirical literature about the importance of international fragmentation of production (i.e., offshoring). A number of papers use industry-level input output (IO) tables to show the importance of offshoring across countries and over time (e.g., Hummels, Ishii, and Yi (2001), Johnson and Noguera (2012)). While these papers provide strong evidence that international fragmentation of production is an important and growing phenomenon, their

\footnotetext{
${ }^{9}$ See Pierce and Schott (2012) for a description and trade-related explanation of the decline in US manufacturing sector employment.
} 
analyses focus on the manufacturing sector. In this paper, we show that when establishments relocate the entire physical production process to another location, they become FGPs and so are no longer included in official manufacturing statistics. As a result, current work that relies on IO tables, or manufacturing more generally, will miss this potentially important type of production fragmentation. ${ }^{10}$

There is also research into the determinants of firms' vertical production networks. One strand of this literature focuses on multinational production to assess production sharing across countries (e.g., Hanson, Mataloni, and Slaughter (2005), Yeaple (2003)). These papers find an important role for wages, distance, taxes and human capital in firms' sourcing decisions. In more recent work, Fort (2013) uses the 2007 Census of Manufactures (CM) to asses the role of labor costs, distance to suppliers, and communication technology in US firms' domestic and foreign fragmentation decisions. While the findings in that paper show that firm use of communication technology significantly increases the likelihood of domestic fragmentation, it does not necessarily lead firms to offshore. Most firms in that paper offshore to low wage countries, but use of communication technology only increases the likelihood of sourcing from high technology countries. An open question is whether these results also apply to offshoring by FGPs that have relocated the entire physical production process overseas.

The vast majority of the existing evidence on international fragmentation is based on manufacturers' decisions to offshore production. In this paper, we show that focusing exclusively on manufacturing misses an important element of production fragmentation. Existing evidence on fragmentation by non-manufactures is much more limited. Bernard, Jensen, and Schott (2009) and Bernard, Jensen, Redding, and Schott (2010) show that firms with wholesale establishments account for more than 40 percent of US imports. However, these papers are silent on the relationship between wholesalers and production fragmentation, either domestic or foreign. ${ }^{11}$

The paper also relates to the theoretical literature on offshoring by providing evidence on the types of producers who fragment, the extent to which they do so, and their import activity. Grossman and Rossi-Hansberg (2008) conceptualize the production process in terms of tasks that are costly to separate from the headquarter location. The FGPs documented here provide some of the first direct evidence on establishments that have completely outsourced their production activities. Baldwin and Venables (2010) take the physical production process seriously to distinguish between "snakes", in which production is sequential, and "spiders" in which multiple parts can be made at the same time. This paper highlights the importance of extending the concept of production to include product design and engineering. In this sense, the theoretical framework in Antràs and

\footnotetext{
${ }^{10}$ While the IO tables do include information for the wholesale sector, it is at such a high level of aggregation that it does not allow for a comparable analysis.

${ }^{11}$ The new empirical literature on intermediaries in exports implicitly or explicitly assumes that wholesale firms are merely reselling goods from other producers, i.e. acting as traditional wholesale resellers, see Akerman (2010), Blum, Claro, and Horstmann (2010), and Bernard, Grazzi, and Tomasi (2011).
} 
Helpman (2004) is closely related to the producers we describe here. In that paper, producers combine headquarter services with intermediate good production that can occur within or outside the boundaries of a producer's firm and country. The FGPs we identify provide the precise type of headquarter services modeled in Antràs and Helpman (2004) and source their intermediate inputs both domestically and offshore.

Although Antràs and Helpman (2004) is one of the few theoretical papers to consider both domestic and foreign fragmentation within the same framework, a burgeoning empirical literature explores the domestic fragmentation option. Fort (2013) shows that US manufacturers that fragment production domestically are far more prevalent than those that offshore. Using IO tables for the US, Fally (2012) assesses the number of production stages within industries and over time. While that paper documents a decrease in production fragmentation over time, we note that the emergence of FGPs introduces error into the IO tables since they do not capture outsourcing by wholesalers. Akerman and Py (2011) employ firm-level data on Swedish manufacturers to show that firms in large cities contain fewer occupations, consistent with the premise that these firms are specialized in a smaller range of tasks. The FGPs documented in this paper have undertaken an extreme form of fragmentation in which all the physical production processes have been relocated to another location. To the extent that domestic fragmentation allows for gains to specialization, it represents a dimension of firms' organizational choices with potentially large aggregate productivity effects.

Our paper is most closely related to several recent working papers on measuring the extent of FGP activity in the US economy. Doherty (2013) looks at the response of international and US statistical organizations to the phenomena of rapid improvements in ICT and transportation and the resulting increase in offshore outsourcing. Kamal, Moulton, and Ribarsky (2013) analyze data on contract manufacturing services (CMS) from US firm surveys focusing on the 2011 Company Organization Survey. They find that five percent of US firms purchase CMS and four percent supply CMS with one percent both supplying and purchasing. Bayard, Byrne, and Smith (2013) present a case study of FGP semiconductor production identifying domestic establishments of FGP firms with a unique dataset combining outside company directories of FGP semiconductor firms with Economic Census data for 2002 and 2007. Within wholesale trade, they find that FGP establishments are larger in terms of both employment and sales, their employees have higher average earnings, and they are more geographically concentrated than establishments of other firms. This paper revisits the definition of an FGP and expands the analysis to cover the entire wholesale sector.

\section{Data}

The data employed in this paper are from the 2002 and 2007 US Census Bureau Census of Wholesale Trade $(\mathrm{CW})$. The $\mathrm{CW}$ is conducted in years that end in 2 and 7 and covers the universe of establishments classfied in the Wholesale Trade sector. The data analyzed here are from a new set 
of "Establishment Activities" (EA) questions that were asked in the 2002 and 2007 censuses. In 2002, the CW asked each establishment whether i) Product design/engineering, and ii) Materials fabrication/processing/assembly/blending were a) performed by the establishment; b) performed for the establishment by another company; or c) not provided by the establishment. In 2007, the CW asked each establishment whether i) it designed, engineered, or formulated the manufactured product it sold, produced, or shipped; ii) its primary activity was to provide contract manufacturing services for other establishments, manufacture its own goods, resell goods produced by others, or other; and iii) it purchased contract manufacturing services from another establishment (within or outside the firm) to process its inputs. Copies of the exact questions as they appeared in the censuses are in the appendix.

The EA data are not available for every wholesale plant. In 2002, all establishments in every wholesale industry were asked the EA questions. In 2007, only establishments in 49 of the 71 NAICS industries were sent a form with the EA questions. ${ }^{12}$ All establishments that receive a census form in the mail are legally required to return the completed form. Despite the legal requirement, a number of establishments in both years did not respond to the question. The appendix provides a list of the excluded wholesale industries in 2007 and discusses sample selection issues.

Establishments are given a single industry (sector) classification based on their production process, i.e. they can either be classified as Manufacturing or Wholesale Trade but not both. However, a given establishment may perform activities in both sectors and have employment in both sectors. The practical implication of the assignment process is that plants in the Wholesale Trade sector may, and many do, perform some physical transformation activities. ${ }^{13}$ These wholesale establishments' manufacturing activities are not captured by aggregate statistics since all employment and sales are designated to an establishment's uniquely assigned industry and sector.

The EA data are also available for manufacturing establishments in 2007. The Census of Manufactures (CM) included the same set of Establishment Activities questions asked on the $2007 \mathrm{CW}$. For manufacturers, all large plants and all plants that belong to multi-unit firms, as well as a random sample of small and medium-sized plants within industries, were asked the EA questions. The smallest manufacturing plants, generally those with fewer than five employees, are never surveyed. ${ }^{14}$ The EA data on manufacturers allow us to compare FGPs in the wholesale sector to manufacturing establishments that are similar along several key dimensions.

We supplement the EA data with additional establishment and firm-level variables. Sales, employees, and wages are available in the censuses. We link the census data to the Longitudinal

\footnotetext{
${ }^{12}$ In practice, there are answers to the EA questions in every industry since information was collected from establishments that switched from one of the included 49 industries in 2002 into an excluded industry in 2007.

${ }^{13}$ See Appendix A for more detail.

${ }^{14}$ Manufacturing has short and long forms, and only the long forms asked the EA purchase questions. While all large and multi-unit firm establishments receive the long form, only a random sample of small, single-unit firms received the long form. Data for the smallest establishments is imputed from Federal tax returns and industry averages.
} 
Business Database (LBD) to determine establishment and firm age, as well as the firm's employment in all other sectors. We also link the census data to Customs Trade Transactions data to obtain measures of each firm's imports. The Customs data provide value, transaction type (whether the imports are intra-firm), country, and product information at the firm level.

We construct a value-added labor productivity measure for establishment $i$ as $v a p_{i}=v a_{i} / t e_{i}$, where $v a$ denotes value-added and te denotes total employment. For manufacturing establishments, value-added is provided in the census. For wholesalers, we calculate a proxy measure for value-added as $v a_{i}=$ sales $_{i}-$ merch $_{i}-i n v b_{i}+i n v e_{i}$, where merch $_{i}$ denotes the establishment's purchases of merchandise for resales and $i n v b_{i}$ and $i n v e_{i}$ denote inventory at the beginning and end of the year respectively. It may therefore be more appropriate to think of wholesaler productivity as a gross-margin, but this provides the most comparable productivity measure available for wholesale establishments given the existing data. Establishment sales, employment, wages and productivity all vary significantly across industries. To make meaningful comparisons of these variables across establishments in different industries, we provide information on a relative measure for each characteristics, $x_{i j} / \bar{x}_{j}$, where $\bar{x}_{j}$ is the mean of variable $x$ in industry $j$.

At first glance, manufacturing production by wholesalers appears paradoxical. Traditional wholesalers simply distribute goods and have no involvement in the manufacturing process. While the majority of wholesalers still function as distributors, the sector has evolved to include establishments that design, market and sell their own goods. Because these establishments perform few or no physical transformation activities, they are classified as wholesalers. From an economic theory perspective, however, plants that design goods and coordinate their production are closer to manufacturers than distributors. As such, the wholesale sector contains plants whose behavior sheds light on manufacturing activity in the US economy. ${ }^{15}$

\section{Design and manufacturing at wholesale establishments}

Since individual establishments (plants) are assigned a single primary industry code, each plant is covered by only one sector of the quinquennial Economic Census. ${ }^{16}$ As discussed above, in 2002, every establishment in the Census of Wholesale Trade was asked questions about its activities in product design and manufacturing. We focus on these questions to explore the manufacturing-

\footnotetext{
${ }^{15}$ The Census Bureau has recognized this issue and attempted to address it in the 2017 Economic Census by identifying every manufacturing or wholesale establishment that does not perform its own manufacturing activities, but "undertakes all of the entrepreneurial steps and arranges for all required capital, labor, and material inputs required to make a good" (OMB (2010), pp. 3-4). In 2017, these establishments will be classified in the manufacturing industry that corresponds to the good they sell, with an additional flag identifying them as factoryless goods producers (FGPs). The flag will distinguish FGPs from the traditional "integrated manufactures" (IMs) that perform their own transformation activities, and establishments whose main activity is to provide contract manufacturing services for others (referred to as manufacturing service providers or MSPs).

${ }^{16}$ For example a plant is either in the Economic Census in the Manufacturing Sector or in the Wholesale Sector but not both. This is true even if the plant performs both activities.
} 
Figure 2: Design and Manufacturing Activities at Wholesale Establishments - 2002

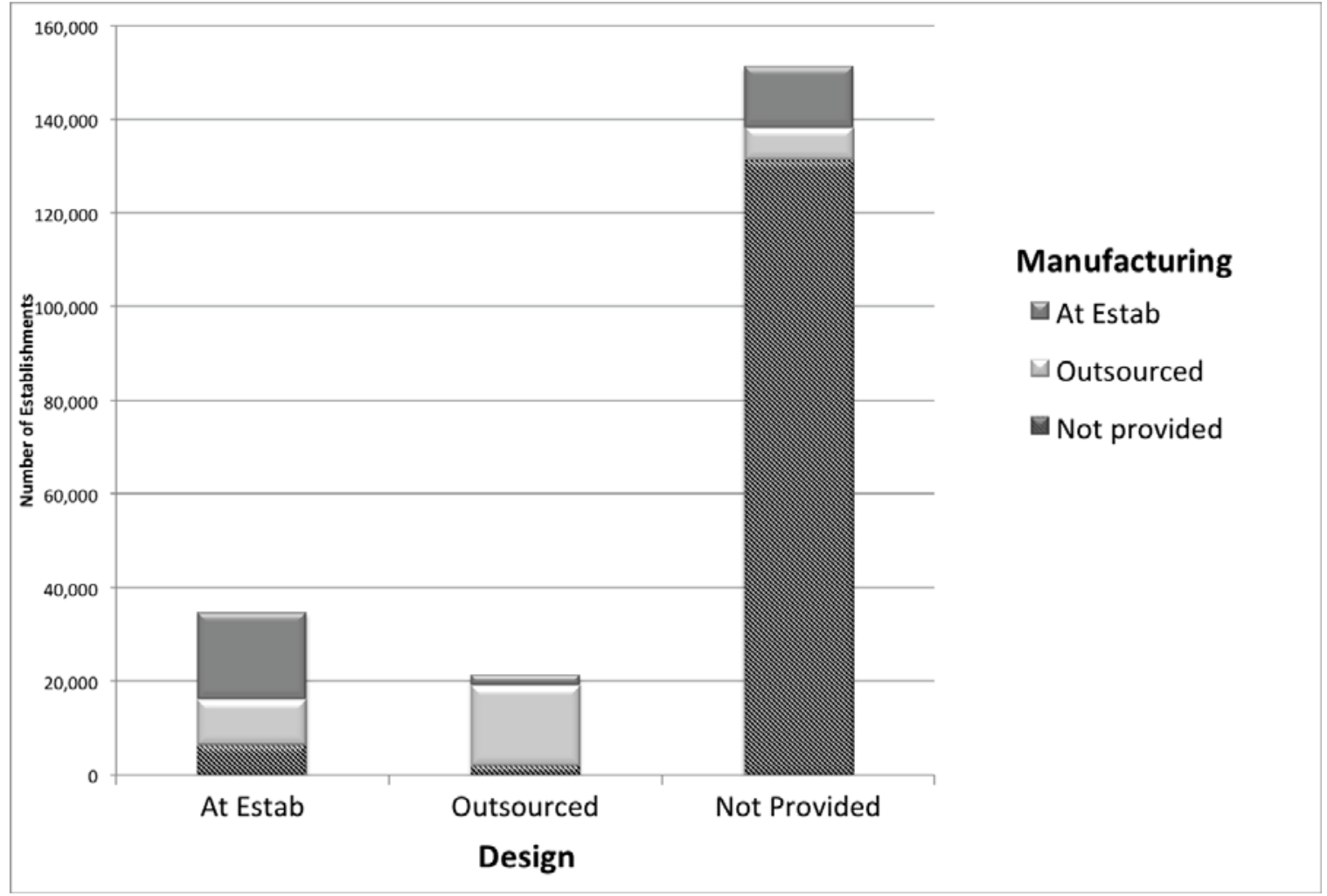

related activities of wholesale establishments and ultimately to create a formal definition of an FGP plant.

\section{2}

In Table 1, we tabulate the counts of plants in the wholesale sector that responded to both the Design and Manufacturing questions in the 2002 Census. ${ }^{17}$ In each case, a plant could either perform the activity at the plant, have it provided by another company, or not provide the activity. Of the 207,494 responding establishments, 63.2 percent participated in neither design or manufacturing activities, either inside the plant or purchased from another firm, see Figure 2. These plants match the typical perception of a wholesaler that is not involved in the creation of the product but rather is active in delivery, warehousing, order fulfillment, logistics or other services that intermediate between a producer and a customer.

However, more than 36 percent of wholesale establishments are involved in either design or manufacturing activities or both. Almost a third of the responding wholesale plants are involved in manufacturing, evenly split between plants that are doing manufacturing themselves or those purchasing contract manufacturing services. Similarly more than a quarter of wholesale plants are

\footnotetext{
${ }^{17}$ The exact questions from the $2002 \mathrm{CW}$ can be found in Figure 4. Many more plants responded to one of the two questions. The distribution of responses was similar for plants answering one or two questions.
} 
involved in design and engineering activities; 16.8 percent design at the establishment while 10.0 percent outsource design activities to others. These results challenge the stereotype of a wholesale establishment that simply intermediates between producer and consumers. The wholesale sector is a heterogeneous mix of traditional resellers and plants that are actively involved in production activities.

There is also new evidence in the other direction, i.e. that manufacturing firms are increasingly producing services. Crozet and Milet (2013) document the shift away from goods towards services in French manufacturing firms. They find that one third of French manufacturing firms have more than half of their revenue from services.

Plants that perform design activities themselves are most likely to conduct manufacturing activities as well, or to have manufacturing provided by an outside company. More than 1 in 12 wholesale plants both design and manufacture at the establishment itself. For those plants that outsource design activities, a large majority (more than 80 percent) also contract for manufacturing services.

\section{7}

As discussed above, the coverage and format of the questions changed between the 2002 and 2007 Economic Censuses. In Table 2 we report three dimensions of the underlying sample of plants for 2007: those that did or did not perform design activities at the plant, the primary activity of the plant, and whether or not the plant contracted for manufacturing services, either inside or outside the US. To be included in the table, an establishment had to provide a response to all three of the questions. $^{18}$

Of the 140,726 responding establishments, 15.2 percent indicated that they perform design activities at the plant, down slightly from 2002. More than a fifth of wholesale plants (21.5 percent) are involved in activities related to manufacturing either through the purchase or sale of contract manufacturing services or because they report their primary activity to be manufacturing. There is substantial variation in manufacturing activities depending on whether or not the plant does design in-house. 67.5 percent of designing establishments buy or sell CMS or have their primary activity as manufacturing. Only 13.3 percent of non-design plants are similarly involved in manufacturing activities.

For these plants with no design activities, 95.2 percent report their primary activity to be in "resales" or "other". These establishments conform to the traditional view of a wholesalers. The remaining 5,678 establishments with no design activity at the plant describe their primary activity as manufacturing or contract manufacturing for others.

\footnotetext{
${ }^{18}$ The exact questions from the $2007 \mathrm{CW}$ form can be found in Figure 5. This requirement that a plant provides an answer to all three questions results in the smaller sample size in Table 2 than in Table 1 . One and two-way tabulations that are not limited to the subset of plants that responded to all three questions result in comparable percentages of plants across the categories.
} 
Figure 3: Design and Manufacturing Activities at Wholesale Plants, 2007

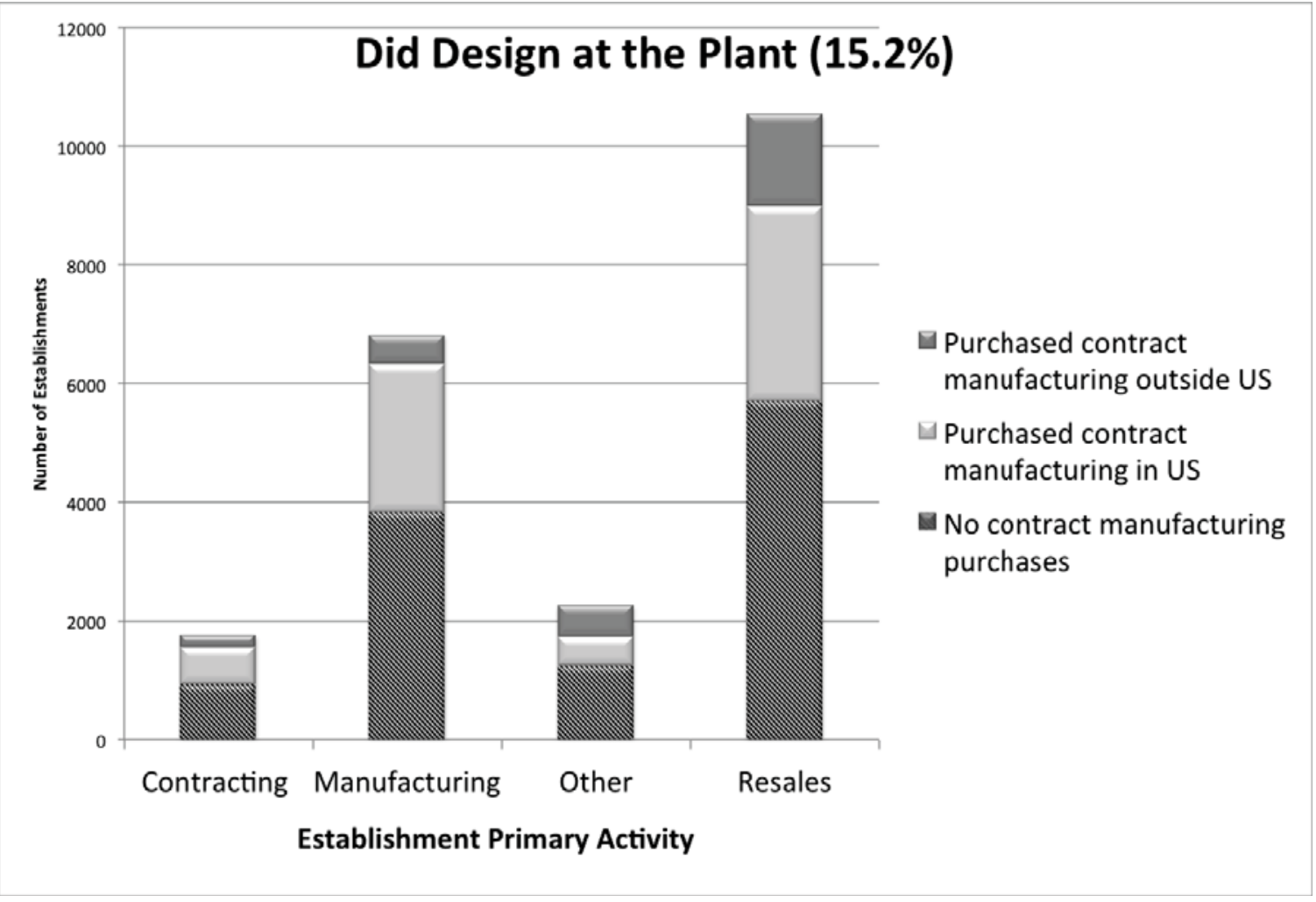

Among the 21,430 establishments that do report design activities, 6,829 (31.9 percent) report their primary activity as manufacturing and another 8.3 percent are primarily contract manufacturers for other companies, see Figure 3. Although categorized as wholesalers, these plants are performing a substantial range of manufacturing-related activities. Even among establishments that describe themselves as resellers (or other), almost 46 percent are purchasing contract manufacturing services from domestic or foreign locations in addition to their own design activity.

The 2007 questions also shed light on the role these non-traditional wholesale establishments play in global production chains. Two percent of establishments that do not design their products purchase CMS offshore. In contrast, 13 percent of wholesale plants that design their own goods also offshore customized production (i.e., purchase CMS abroad). Fort (2013) examines offshore CMS purchases in the manufacturing sector and finds that the share of offshoring establishments is close to two percent. The share of designing wholesale establishments that offshore is therefore more than six times the share of manufacturing establishments that offshore. We do note that, as in the results for manufacturing reported in Fort (2013), establishments with domestic CMS purchases are still more prevalent than establishments with offshore purchases. ${ }^{19}$

In both 2002 and 2007, a sizable fraction of wholesale plants are conducting a range of manufacturing-

\footnotetext{
${ }^{19}$ Fontagné and D'Isanto (2013) find that 4.2 percent of French non-financial firms source activities from abroad.
} 
related activities from design to the purchase of contract manufacturing services to manufacturing itself. Establishments that perform design are much more likely to have manufacturing activity at the plant or purchase contract manufacturing than plants that report no design activities.

\section{Factoryless Goods Producers}

The results above suggest that there are multiple types of wholesale plants engaged in a range of activities related to the production and distribution of manufactured goods. Both national statistical agencies and researchers are faced with the difficult question of how to conceptually and practically define an establishment that performs a sufficient range of manufacturing-related activities to be categorized as a factoryless goods producer. Whether or not FGPs should be moved from nonmanufacturing sectors to manufacturing is a separate question. ${ }^{20}$ Not every wholesale plant that does design, purchases contract manufacturing services, or manufactures onsite should qualify for this change in status. The range of manufacturing-related activity must be sufficient to cover both the conceptualization and fabrication of a good. Additional complications arise from the variation in underlying survey questions over time.

\subsection{Definition of a Factoryless Goods Producer}

Our definition is based on a combination of activities at the plant: the wholesale establishment must perform design (pre-production) and be involved in manufacturing in some capacity (physical transformation activities). Wholesale establishments by definition are also involved in post-production activities.

Definition 1. A Factoryless Good Producer (FGP) is a wholesale establishment that performs design/engineering/R\&D activity at the establishment and either conducts manufacturing operations at the establishment itself or purchases manufacturing services from a domestic or foreign company.

By this definition the wholesale plant has manufacturing-related activity both before (design) and during the production of the good. Wholesale establishments that are not FGPs (non-FGPs) include those that contract for design services, those that report no purchases of contract or onsite manufacturing even if design itself is occurring at the establishment, and those that are not involved in product design at all. ${ }^{21}$ In theory the definition covers all wholesale establishments and divides them into FGPs and non-FGPs. In practice, wholesale establishments might not be able to be

\footnotetext{
${ }^{20}$ One practical reason to classify FGPs in the manufacturing sector is to ensure adequate data collection. The CM collects much more detailed information on the inputs and outputs of the physical production process.

${ }^{21}$ International and US definitions of FGPs differ according to the ownership of inputs but both use a definition that ignores manufacturing activity at the establishment. Using the same CW data, Bayard, Byrne, and Smith (2013) adopt a version of this narrower definition of an FGP as a wholesale establishment that performs design and purchases contract manufacturing services. Wholesale establishments that both design and manufacture onsite are excluded from these definitions but are included in ours.
} 
categorized if they did not answer the relevant questions about design and manufacturing and thus will be classified as Missing. ${ }^{22}$ The implementation of our definition varies between 2002 and 2007. We caution that comparisons across the years are difficult both due to changes in the underlying sample of responding establishments as well as to changes in the nature of the questions in the Economic Censuses.

\subsection{FGPs in 2002}

For 2002, using our definition, an FGP is an establishment in the wholesale sector that reports design activity in-house and either conducts manufacturing activity itself or purchases manufacturing services from outside the company. ${ }^{23}$ These criteria mean that, for the $2002 \mathrm{CW}$, the establishment must have provided an answer to both the design and manufacturing questions to be classified as an FGP. 24

The upper panel of Table 3 reports the counts of FGP and non-FGP plants in the wholesale sector along with their total sales and employment, while the bottom panel of the table provides similar totals for the population of wholesale and manufacturing establishments. We are able to classify almost half of the wholesale establishments in 2002 according to their FGP status. Of the plants with non-missing FGP status, 13.5 percent are Factoryless Goods Producers doing both design and manufacturing activities. ${ }^{25}$ The FGP plants have $\$ 253 \mathrm{~B}$ in sales and employ 595,000 workers. Compared to the population of wholesale establishments, FGP establishments represent 6.5 percent of total establishments and account for 10.2 percent of employment and 5.2 percent of output. ${ }^{26}$

\subsection{FGPs in 2007}

As mentioned earlier, the questions about manufacturing-related activities at the establishment changed between the 2002 and 2007 Censuses. In addition in 2007 not every wholesale industry was asked the questions. To qualify under our definition of FGP in 2007, a plant had to either (a)

\footnotetext{
${ }^{22}$ In practice it is sometimes possible to classify a plant based as non-FGP based on their answer to a single question. For example, if they indicate they did no design but did not answer the other questions or if they indicate they were not involved in manufacturing at the plant or through the purchase of contract manufacturing services but gave no information about their design activity.

${ }^{23}$ In 2002, the Economic Census does not distinguish between domestic and foreign contract manufacturing purchases.

${ }^{24}$ However, we are able to categorize some plants as non-FGP even if they answered only one of the questions on design or manufacturing. All plants with no design and all plants that report no manufacturing are classified as non-FGP (regardless of their answer to the other question) and as a result the total number of plants in Table 3 is greater than the totals in Table 1.

${ }^{25}$ These 28,331 FGP establishments represent the sum of the 18,539 plants that did design and manufacturing at the plant (Table 1 row 1 column 1) and the 9,792 plants that did design at the plant and purchased CMS (Table 1 row 1 column 1 ).

${ }^{26}$ We caution that these shares represent the activity at plants we can identify as FGP, i.e. a lower bound, as the FGP status of more than half of plants in the Wholesale sector is missing.
} 
do design and have its primary activity as Manufacturing, Contracting, or Other or (b) do design with the primary activity of Resales and purchase contract manufacturing services. A plant was non-FGP if it either (a) did not perform design or (b) did design with the primary activity of Resales but did not purchase contract manufacturing services.

Table 4 gives plant, sales and employment totals for FGP and non-FGP plants in 2007 in the upper panel. The numbers of plants that are classified as FGP or non-FGP drops between 2002 and 2007 even as the population of wholesale establishments grows slightly. ${ }^{27}$ This is likely due to the difference in the questions asked in the 2007 Census, the need for responses to three questions instead of two, and the fact that not all industries in the Wholesale Trade sector were asked the EA questions. Of the wholesale plants with non-missing status in 2007, 10.5 percent are classified as FGP with $\$ 279 \mathrm{~B}$ in sales employing 431,000 workers.

Interestingly, in the 2007 Economic Census, a subset of manufacturing establishments was asked the same questions about design, primary activity and CMS purchases and thus we are able to classify manufacturing firms according to the same criteria. The majority of manufacturing establishments with non-missing data satisfy the FGP criteria (58.4 percent) and they account for just under half of total manufacturing sales and employment.

\section{Characteristics of FGP Establishments}

In this section we compare FGP establishments, non-FGP establishments, all wholesalers, and manufacturing establishments in terms of employment, wages, sales, labor productivity, and age. As there is no formal theoretical guidance from the literature on how these characteristics should vary across plant types, we describe two possible wholesale establishments. The FGP plant creates, designs and engineers the product itself and coordinates the production, possibly through the purchase of CMS. Wholesale status means it is likely that the establishment is involved in post-production logistics and distribution. The traditional wholesale establishment (non-FGP) is not involved with pre-production activities, purchases the finished good directly form the producer, and is primarily involved in post-production activities.

The addition of the design activities would tend to raise employment and measured value-added at the FGP plant, especially when adjusting for total sales. If pre-production workers are relatively skill intensive, average wages would also be higher at the FGP facility. Sales volume itself might be higher at the non-FGP plant, especially sales per employee, in part because the traditional

\footnotetext{
${ }^{27}$ The 16,752 FGP establishments in 2007 represent the sum of the 10,881 plants that did design at the plant and had Contracting, Manufacturing or Other as their primary activity (Table 2 rows 1-3 column 4) and the 4,842 plants that did design at the plant,purchased CMS, and had Resales as their primary activity (Table 2 row 4 columns 1-2). Note that these numbers sum to only 15,723 since Table 2 is limited to establishments that answered the design question, the primary activity question and the CMS question. In contrast, FGP status is defined for all plants that answered the design question and at least one of the primary activity and CMS questions.
} 
wholesaler is likely to handle a wider variety of goods in any given market.

\section{2}

Table 5 reports unweighted means for each characteristic by plant FGP status in the top panel for 2002. Since differences in the means can come from a combination of within industry differences at FGP and non-FGP plants and the mix of industries in the sample of plants with non-missing FGP status (and the industry mix difference between FGP and non-FGP) we report the average unweighted ratio (or log difference) relative to the mean in the industry of the establishment in the middle panel. The bottom panel in the table gives unweighted means across all establishments in the wholesale and manufacturing sectors for comparison.

Within the sample of establishments where we can identify FGP status, we find that FGP plants have much lower sales and log value-added per worker than traditional wholesale plants (non-FGP), while employment is substantial larger and the average wage is comparable. They are also slightly younger.

The middle panel shows the extent to which the differences between FGPs and non-FGPs depend upon the industry composition of each group. In this panel, a value of one indicates that a plant is exactly at its industry mean (zero for $\log \mathrm{VA} /$ worker). First, it is clear that, on average, plants in the FGP sample are larger and more productive than establishments with a missing status. Both FGPs and Non-FGPs have values greater than one. Second, the relative means reveal important within-industry differences from the raw averages presented in the top panel. Although non-FGPs still have more sales than FGPs, their relative mean is only 4.7 percent larger than the FGP mean, whereas the raw numbers suggested a 41 percent difference in size. In contrast, the relative means reveal even bigger differences in employment at FGPs versus non-FGPs. FGPs employ 1.67 times more workers than their industry average, compared to just 1.15 times for Non-FGPs.

\section{7}

We repeat the exercise for 2007 in Table 6. Within the sample of wholesale establishments where we can identify FGP status, we find that FGP plants have somewhat lower sales and substantially higher employment than traditional wholesale establishments as in 2002. However in this sample, FGP plants on average have higher wages and comparable, rather than lower, productivity. FGP plants are also younger than non-FGPs.

Looking at the middle panel, we find that relative to their industry averages, FGP establishments have substantially higher sales, wages, productivity and especially employment. On average, FGP plants are also larger, more productive, and pay higher wages than non-FGP plants in the same industry. 


\section{FGP Firms}

Having established a number of plant-level facts, we turn our focus to the firm. While the Economic Censuses collect information at the unit of the establishment, economic decision-making in many cases takes place at the firm level. Most firms in both manufacturing and wholesale trade are singleplant (SP) organizations but the smaller number of multi-plant (MP) firms are disproportionately important in aggregate output, and employment and are more likely to produce multiple products (see Dunne, Roberts, and Samuelson (1988) and Bernard, Redding, and Schott (2010)). For SP firms, FGP status is a straightforward application of Definition 1; however, for MP firms we need a new definition.

Definition 2. A Factoryless Good Producing Firm (FGPF or FGP firm) is a firm with at least one FGP wholesale establishment.

The practical implementation of Definition 2 is complicated by the fact that each wholesale plant can be in one of three categories: FGP, non-FGP, or Missing. As a result, firms can also be in one of three categories: $F G P F$ - at least one wholesale plant is an FGP, non-FGPF where none of the wholesale plants at the firm is identified as an FGP and at least one plant is identified as not being an FGP, and Missing - where every wholesale plant in the firm has Missing for its FGP status. $^{28}$

MP firms can be comprised of only wholesale establishments, a mix of manufacturing and wholesale establishments and only manufacturing establishments. FGP firms come from the the first two firm types, any firm that has no wholesale (only manufacturing) establishments is not an FGPF. ${ }^{29}$

Table 7 reports the number of firms by FGP status and Firm type in 2002 (upper panel) and 2007 (lower panel). In 2002, 16.5 percent of the firms with non-Missing status are FGPFs and only a small fraction of FGPFs are Mixed firms. However, FGPFs are almost twice as likely to be a Mixed firm (3.8 percent) than are non-FGPFs (2.0 percent) or Missing firms. For 2007, as with the plant-level data, fewer firms have non-missing FGPF status and among those a smaller fraction are FGPF. Again the share of Mixed firms among FGPFs is much higher (5.3 percent) than for non-FGPFs (2.0 percent)

Table 8 reports on firm characteristics by FGPF status and Firm type (upper panel) as well as by Census (lower panel) for 2002. ${ }^{30}$ The comparable firm characteristics for 2007 are given in Table 9. Sales, employment, and imports are much larger at FGPFs than at other types of firms (non-FGPF

\footnotetext{
${ }^{28}$ We note that this is a conservative definition of an FGP firm since a plant with missing status at a non-FGP firm may be an FGP. An alternative definition would have classified all firms with one or more plants with a missing status as Missing. However, this classification scheme would likely have resulted in a much bigger allocation of the larger, MP firms to the Missing category.

${ }^{29}$ We note that all firms may have employment in other sectors, such as Retail Trade or Business Services, but we do not measure those activities here.

${ }^{30}$ We do not report normalization within industries due to the multi-industry nature of many firms.
} 
or Missing) in both years. FGPFs also have more manufacturing plants on average (almost four times as many in 2002 and five times as many in 2007) than non-FGPFs. A portion of these differences is driven by the increased presence of Mixed firms in the FGPF category. Within each group, Mixed firms are dramatically larger, more productive, and more involved in imports. Despite this compositional component, the Mixed FGPFs are still different from the Mixed non-FGPs. They are more productive and have more sales, employment, and imports than the non-FGPFs. In addition, the Mixed FGPFs have twice as many manufacturing and wholesale establishments on average than non-FGPFs in both 2002 and 2007.

Tables 8 and 9 also show the average share of intra-firm (related party) imports by FGP status and firm type. The share of intra-firm imports for Mixed firms is between 0.25 and 0.27 for both FGPFs and non-FGPFs in 2002 and 2007. In contrast, FGPF Wholesale-only firms have a noticeably lower share of intra-firm imports compared to non-FGPFs. In 2002, the average share of intra-firm imports for FGPFs was only 0.09 compared to 0.13 for non-FGPFs. A similar pattern is evident in 2007. Wholesale-only FGPFs had an average share of intra-firm imports of 0.08 compared to 0.13 for non-FGPs.

\section{$7 \quad$ Aggregate Implications}

In this section we consider how employment and output aggregates for manufacturing would have been different if FGP establishments had been included in the manufacturing sector in 2002 and 2007 instead of in the wholesale sector. In 2017, the US Census Bureau is scheduled to do exactly this by recording FGPs in the manufacturing sector. We emphasize that the results in this section depend on our definition of FGP in each year. The difference in the survey questions and coverage over time makes even the comparison of the 2002 and 2007 numbers problematic.

A major concern for policymakers in advanced, industrialized economies has been the rapid and systematic decline in the manufacturing sector in recent decades. The focus of this paper is on the presence of FGPs that reside outside the manufacturing sector but conduct manufacturing-like or manufacturing-related activities. Broadly construed FGPs employ workers and produce output that is similar in many dimensions to traditional manufacturing operations but their employment and output do not count towards manufacturing aggregates.

Here we report the results of two exercises that shift FGPs to the manufacturing sector with adjustments to the aggregate manufacturing employment and output statistics. ${ }^{31}$ In the first ad-

\footnotetext{
${ }^{31}$ Using a narrower definition of FGPs and focusing on the semiconductor industry, Bayard, Byrne, and Smith (2013) estimate that US manufacturing output would have been 7-30 percent higher in 2002 and 2007 if FGPs has been included. We consider FGPs more broadly and include a focus on employment which is typically the focus of policy debates on the manufacturing sector. They find a larger share of output in FGPs in the semiconductor sector than we do for manufacturing overall. This difference might exist in part because the semiconductor industry has undergone more production fragmention than the average manufacturing sector.
} 
justment, we add employment (output) by establishments that we have identified as FGPs in 2002 and 2007 to existing manufacturing aggregates. In the second adjustment, we assume that the prevalence of FGPs in our samples of responding establishments holds for the entire population of wholesale plants and that employment and output at all those plants differs from their industry means to the same extent as found in the samples of responding establishments. The two methods provide rough lower and upper bounds on the extent of manufacturing-like activity due to the presence of FGPs in the Wholesale Trade sector. To the extent that FGPs are present in other sectors, such as Business Services, both of our estimates may understate the presence of FGPs and their employment and output.

The first method is quite straightforward and merely involves adding the employment and output aggregates at establishments identified as FGP in Section 4 to the reported manufacturing totals for each year. Reclassifying FGP establishments to the manufacturing sector would have increased reported manufacturing jobs by 595,000 in 2002 and by 431,000 in 2007, corresponding to an 4.0 percent increase in manufacturing employment in 2002 and 3.2 percent increase in 2007. The same method of adjustment would have resulted in increased reported manufacturing output by $\$ 253 \mathrm{~B}$ (6.5 percent) in 2002 and by $\$ 279 \mathrm{~B}$ (5.2 percent) in 2007.

The second method involves two strong additional assumptions. First, we assume that the fraction of FGPs in the overall wholesale sector is the same as that among those plants answering both the design and manufacturing questions in 2002, and those answering the design, primary activity and outsourcing questions in 2007. Second, we assume that all these FGPs are proportionally different from (larger than) the average in their industry in terms of employment and output to the same degree as the observed FGP plants (see Tables 5 and 6).

Applying the first assumption results in 58,147 FGPs in 2002 and 45,624 FGPS in 2007. Average employment at wholesale plants was 13.5 workers in 2002 and 14.3 workers in 2007 and the withinindustry FPG-adjustment factors were 1.67 and 1.65 respectively yielding an average of 22.5 workers per FGP in 2002 and 23.6 workers per FGP in 2007.

This more liberal set of assumptions results in 1,311,000 more manufacturing jobs in 2002 and 1,934,000 in 2007, 9.0 percent and 14.4 percent respectively. The same method of adjustment would have resulted in increased reported manufacturing output by $\$ 758 \mathrm{~B}$ (19.4 percent) in 2002 and by \$895B (16.8 percent) in 2007.

\section{Conclusions}

Large numbers of workers in the wholesale sector are employed at plants that engage in manufacturingrelated activities. Unlike traditional wholesalers, these establishments are not primarily engaged in intermediation but instead undertake design and engineering of products themselves and exert control over the production process. To date, many of these factoryless goods producers have been 
hidden in the wholesale sector. Our findings open a window into the extent and characteristics of FGPs in the US wholesale sector. The potential for increasing fragmentation of production across firms and borders means that FGPs are likely to play an even larger role in industrialized economies in years to come.

The findings in this paper raise issues for academic researchers and statistical agencies. There is the relatively straightforward question of how to assign FGPs to broad sectors such as manufacturing or wholesale trade. Our results suggest that merely asking plants about their outsourcing activities might miss an important segment of FGPs, those that design their goods and still do some manufacturing but not enough to be reclassified as traditional manufacturers. Our findings suggest that moving FGPs to manufacturing will substantially raise measured manufacturing employment. These results also raise questions about the production process itself and how it is fragmented across locations and firms. Measurement of output and inputs may be fundamentally different at FGPs than at integrated manufacturing firms or at more traditional wholesalers with obvious consequences for measuring value-added and productivity. The presence of FGPs in an industry also complicates the already-difficult job of measuring productivity, both within FGPs over time and between FGPs and other plants. We lack evidence on their production function, or on how their existence may bias existing estimates of productivity.

Our results suggest a fruitful area of research related to theoretical models of tasks, outsourcing and offshoring. The largely neglected wholesale trade sector contains a sizable number of establishments that are at the forefront of this type of production fragmentation. The FGPs we document in this paper suggest that, at least for some producers, it is optimal to fragment the majority of the physical transformation activities to another location. We also find that these plants are systematically different from integrated manufacturers or traditional wholesale intermediaries. Rodríguez-Clare (2010) develops a dynamic model of offshoring in which the reallocation of factors of production away from manufacturing and towards design activities can result in long-term productivity gains for the offshoring country. The factoryless goods producers we document in this paper provide evidence of a production process that is consistent with this mechanism. However, our results only provide a snapshot of FGPs at two points in time. We know nothing about how they are created, for example whether they are new establishments or transformations of existing ones, or how they perform over time in terms of output, employment growth, and survival. 


\section{References}

Akerman, A. (2010): "A theory on the role of wholesalers in International trade based on economies of scope," Research papers in economics, Stockholm University, Department of Economics. 11

Akerman, A., And L. Py (2011): "Outsourcing and the Division of Labor between Firms: Evidence from Swedish Cities," mimeo, Stockholm University. 1

Antràs, P., And E. Helpman (2004): "Global Sourcing," Journal of Political Economy, 112(31), $552-580.1$

Baldwin, R., And A. Venables (2010): "Relocating the Value Chain: Offshoring and Agglomeration in the Global Economy," NBER Working Paper 16611. 1

Bayard, K., D. Byrne, and D. Smith (2013): "The Scope of U.S. Factoryless Manufacturing," mimeo, Federal Reserve Board. 4, 1, 21, 31

Bernard, A. B., M. Grazzi, and C. Tomasi (2011): "Intermediaries in International Trade: Direct versus indirect modes of export," NBER Working Papers 17711, National Bureau of Economic Research. 11

Bernard, A. B., J. B. Jensen, S. J. Redding, and P. K. Schott (2010): "Wholesalers and Retailers in US Trade," American Economic Review, 100(2), 408-13. 1

Bernard, A. B., J. B. Jensen, and P. K. Schott (2009): "Importers, Exporters, and Multinationals: A Portrait of Firms in the U.S. that Trade Goods," in Producer dynamics: New Evidence from Micro Data, ed. by T. Dunne, J. Jensen, and M. Roberts. University of Chicago Press. 1

Bernard, A. B., S. J. Redding, and P. K. Schott (2010): "Multiple-Product Firms and Product Switching," American Economic Review, 100(1), 70-97. 6

Blum, B. S., S. Claro, and I. Horstmann (2010): "Facts and Figures on Intermediated Trade," American Economic Review, 100(2), 419-23. 11

Crozet, M., And E. Milet (2013): "Shift from products to related services within firms," Discussion paper, Conference on the Factory-Free Economy. 1, 3

DoherTy, M. (2013): "Reflecting factoryless goods production in the U.S. statistical system," mimeo. 7,1

Dunne, T., M. J. Roberts, and L. Samuelson (1988): "Patterns of Firm Entry and Exit in U.S. Manufacturing Industries," Rand Journal of Economics, 19, 495-515. 6 
FALly, T. (2012): "Production Staging: Measurement and Facts," Working paper, University of Colorado-Boulder. 1

Fontagné, L., And A. D’Isanto (2013): "Fragmentation: Survey-based evidence for France," Discussion paper, Conference on the Factory-Free Economy. 19

FORT, T. C. (2013): "Breaking up is hard to do: Why firms fragment production across locations," working paper, Tuck School of Business. 1, 3

Grossman, G. M., and E. Rossi-Hansberg (2008): "Trading Tasks: A Simple Theory of Offshoring," The American Economic Review, 98(5), 1978-1997. 1

Hanson, G. H., R. J. Mataloni, and M. J. Slaughter (2005): "Vertical Production Networks in Multinational Firms," Review of Economics and Statistics, 87(4). 1

Hummels, D., J. Ishiı, And K.-M. Yi (2001): "The Nature and Growth of Vertical Specialization in World Trade," Journal of International Economics, 54(1), 75-96. 1

Johnson, R., And G. Noguera (2012): "Fragmentation and Trade in Value Added Over Four Decades," Working Paper 18186, NBER. 1

Kamal, F., B. R. Moulton, and J. Ribarsky (2013): "Measuring "factoryless" manufacturing: Evidence from U.S. Surveys," mimeo. 1

Kraemer, K. L., G. Linden, and J. Dedrick (2011): "Capturing Value in Global Networks: Apple's iPad and iPhone," working paper, Personal Computing Industry Center, UC Irvine. 3

OMB (2010): "Economic Classification Policy Committee Recommendation Recommendation for Classification of Outsourcing in North American Industry Classification System (NAICS) Revisions for 2012," Federal register, Office of Management and Budget. 1, 15, B

Pierce, J. R., and P. K. Schott (2012): "The Surprisingly Swift Decline of U.S. Manufacturing Employment," Woking Paper 18655, NBER. 9

Rodríguez-Clare, A. (2010): "Offshoring in a Ricardian World," American Economic Journal: Macroeconomics, 2(2). 8

Yeaple, S. R. (2003): "The Role of Skill Endowments in the Structure of U.S. Outward Foreign Direct Investment," The Review of Economics and Statistics, 85(3), 726-734. 1 


\section{Appendix}

\section{A Data}

The industry classifications for all establishments covered by the economic census and surveys are based on the North American Industry Classification System (NAICS). The method of assigning industry classifications and the level of detail at which establishments were classified depends on whether a report form is obtained for the establishment. Establishments that returned a report form are classified on the basis of their self-designation; product line sales, products produced, or services rendered; and responses to other industry-specific inquiries. Establishments that do not return a report form and those that were not sent a report form were classified using the following methods: (a) the most current industry classification available from the applicable Census Bureau current surveys or the previous economic census, (b) the classification from administrative records of other federal agencies, (c) a brief inquiry requesting information necessary to assign a kind-of-business code and/or (d) research done by Census Bureau analysts.

Figure 4: Census Design and Manufacturing Questions - 2002

\begin{tabular}{|c|c|c|c|c|}
\hline \multicolumn{5}{|c|}{ Form WH-42101 } \\
\hline 27 & Not Applicable. & & & \\
\hline \multirow[t]{5}{*}{28} & \multicolumn{4}{|l|}{ ESTABLISHMENT ACTIVITIES } \\
\hline & \multicolumn{4}{|c|}{$\begin{array}{l}\text { A. Indicate activities that were performed by this establishment or were performed for this establishment by another } \\
\text { company during } 2002 \text {. } \\
\text { (Mark "X" ALL that apply.) }\end{array}$} \\
\hline & \multirow{2}{*}{ 1. Product Development } & $\begin{array}{l}\text { This activity was } \\
\text { performed by this } \\
\text { establishment }\end{array}$ & $\begin{array}{l}\text { This activity was } \\
\text { performed for this } \\
\text { establishment by } \\
\text { another company }\end{array}$ & $\begin{array}{l}\text { This activity was } \\
\text { not provided by } \\
\text { this establishmen }\end{array}$ \\
\hline & & ${ }_{0921} \square$ & ${ }_{0941}^{\square}$ & ${ }_{0961}^{\square}$ \\
\hline & b. Materials fabrication/processing/assembly/blending . . . & $0922 \square$ & ${ }_{0942} \square$ & $0962 \square$ \\
\hline
\end{tabular}


Figure 5: Census Design, Primary Activity and Outsourcing Questions - 2007

Form WH-42301 (12/04/2006)

26 SPECIAL INQUIRIES - Continued

c. OTHER ESTABLISHMENT ACTIVITIES

1. Did this establishment design, engineer, or formulate the manufactured products that it sold, produced, or shipped?

$0318 \square$ Yes

$0319 \square$ No

2. Which of the following best describes this establishment's primary activity? (Mark " $X$ " only ONE box.)
$0362 \square$ Providing contract manufacturing services for others
${ }_{0363} \square \quad$ Transforming raw materials or components into new products that this establishment owns or controls
${ }_{0364} \square$ Reselling goods manufactured by others (with or without minor final assembly)
$0365 \square$ Other - Specify
0300

3. Did this establishment purchase contract manufacturing services from other companies or other establishments of your company to process materials or components that this establishment owns or controls?

$0496 \quad \square$ Yes, primarily with establishments WITHIN the 50 States and the District of Columbia

${ }_{0497} \square$ Yes, primarily with establishments OUTSIDE of the 50 States and the District of Columbia

$0498 \quad \square \quad$ No

Figure 6: Industries not asked the Establishment Activity Questions - 2007

\begin{tabular}{cl}
\hline NAICS Code & NAICS Description \\
\hline 423210 & Furniture Merchant Wholesalers \\
423220 & Home Furnishing Merchant Wholesalers \\
423410 & Photographic Equipment and Supplies Merchant Wholesalers \\
423420 & Office Equipment Merchant Wholesalers \\
423440 & Other Commercial Equipment Merchant Wholesalers \\
423450 & Medical, Dental, and Hospital Equipment and Supplies Merchant Wholesalers \\
423460 & Ophthalmic Goods Merchant Wholesalers \\
423490 & Other Professional Equipment and Supplies Merchant Wholesalers \\
423710 & Hardware Merchant Wholesalers \\
423720 & Plumbing and Heating Equipment and Supplies (Hydronics) Merchant Wholesalers \\
423730 & Warm Air Heating and Air-Conditioning Equipment and Supplies Merchant Wholesalers \\
423740 & Refrigeration Equipment and Supplies Merchant Wholesalers \\
423840 & Industrial Supplies Merchant Wholesalers \\
423990 & Other Miscellaneous Durable Goods Merchant Wholesalers \\
424610 & Plastics Materials and Basic Forms and Shapes Merchant Wholesalers \\
424690 & Other Chemical and Allied Products Merchant Wholesalers \\
424710 & Petroleum Bulk Stations and Terminals \\
424720 & Petroleum and Petroleum Products Merchant Wholesalers (except Bulk Stations and Terminals) \\
424910 & Farm Supplies Merchant Wholesalers \\
424990 & Other Miscellaneous Nondurable Goods Merchant Wholesalers \\
425110 & Business to Business Electronic Markets \\
425120 & Wholesale Trade Agents and Brokers \\
\hline
\end{tabular}




\section{B Definitions of FGPs}

The Economic Classification Policy Committee (OMB (2010)) gives the following definition of an FGP:

The factoryless goods producer (FGP) outsources all of the transformation steps that traditionally have been considered manufacturing, but undertakes all of the entrepreneurial steps and arranges for all required capital, labor, and material inputs required to make a good. Characteristics of FGPs include:

Owns rights to the intellectual property or design (whether independently developed or otherwise acquired) of the final manufactured product;

- May or may not own the input materials;

- Does not own production facilities;

- Does not perform transformation activities;

- Owns the final product produced by manufacturing service provider partners; and

- Sells the final product.

The FGP can provide information on the purchase of the manufacturing service, that is, the cost of the contract, but would not necessarily have production worker payroll or capital expenditures on plant and equipment. However, it can provide data on the number of units that were produced and the market value of the final product. 
Table 1: Design and Manufacturing Activities at Wholesale Plants, 2002

\begin{tabular}{|c|c|c|c|c|c|}
\hline & \multicolumn{4}{|c|}{ Manufacturing } \\
\hline & & At Plant & Outside & No & Total \\
\hline \multirow{4}{*}{$\begin{array}{l}\overrightarrow{0} \\
.00 \\
\vec{D} \\
\mathscr{D}\end{array}$} & At Plant & 18,539 & 9,792 & 6,450 & 34,781 \\
\hline & Outsourced & 2,137 & 17,193 & 2,039 & 21,369 \\
\hline & Not Provided & 13,130 & 6,983 & 131,231 & 151,344 \\
\hline & Total & 33,806 & 33,968 & 139,720 & 207,494 \\
\hline
\end{tabular}

Note: Each cell gives a count of the number of establishments. Establishments had to answer both the Design and Manufacturing questions to be included. Design refers to design or engineering activity in product development. Manufacturing refers to materials fabrication, processing, assembly, or blending. At Plant - activity was performed by this plant; Outsourced/Outside - activity was performed for this plant by another company; No - activity not provided by this plant. All plants were covered by the Census of Wholesale Trade. 
Table 2: Design, Contract Manufacturing, and Primary Activity at Wholesale Plants, 2007

\begin{tabular}{|c|c|c|c|c|c|}
\hline & \multicolumn{4}{|c|}{ Did Design at Plant } \\
\hline & & \multicolumn{4}{|c|}{ Contract Manufacturing } \\
\hline & & In US & Outside US & No & Total \\
\hline \multirow{13}{*}{ 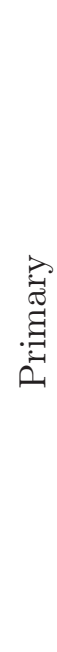 } & Contracting & 632 & 207 & 932 & 1,771 \\
\hline & Manufacturing & 2,507 & 495 & 3,827 & 6,829 \\
\hline & Other & 480 & 545 & 1,256 & 2,281 \\
\hline & Resales & 3,294 & 1,548 & 5,707 & 10,549 \\
\hline & Total - Yes & 6,913 & 2,795 & 11,722 & 21,430 \\
\hline & & \multicolumn{4}{|c|}{ Did Not Design at Plant } \\
\hline & & \multicolumn{4}{|c|}{ Contract Manufacturing } \\
\hline & & In US & Outside US & No & Total \\
\hline & Contracting & 596 & 139 & 1,657 & 2,392 \\
\hline & Manufacturing & 745 & 84 & 2,457 & 3,286 \\
\hline & Other & 821 & 301 & 17,141 & 18,263 \\
\hline & Resales & 7,085 & 1,945 & 86,345 & 95,375 \\
\hline & Total - No & 9,247 & 2,469 & 107,600 & 119,316 \\
\hline
\end{tabular}

Note: Each cell gives a count of the number of establishments. Only establishments that answered the Design, Contract Manufacturing, and Primary Activity questions are included. Design: Did this plant design, engineer or formulate the manufactured products that it sold, produced, or shipped (yes/no)? Primary refers to the establishment's primary activity: Contracting - Providing contract manufacturing services to others; Manufacturing - Transforming raw materials or components into new products that this plant owns or controls; Other - Other (sectorspecific); Resales - Reselling goods manufactured by others (with or without minor final assembly). The Contract Manufacturing question is "Did this establishment purchase contract manufacturing services from other companies or other establishments of your company to process materials or components that this establishment owns or controls?" In US - primarily with plants within the 50 States and DC; Outside US primarily with establishments outside the 50 States and DC; No - No. All plants were covered by the Census of Wholesale Trade. 
Table 3: Plants, Sales and Employment by FGP Status and Census, 2002

\begin{tabular}{|c|c|c|c|}
\hline & \multicolumn{3}{|c|}{ FGP Status } \\
\hline & Plants & Sales & Employment \\
\hline No & 181,671 & 2,750 & 2,897 \\
\hline Yes & 28,331 & 253 & 595 \\
\hline Total & 210,002 & 3,003 & 3,492 \\
\hline \multicolumn{4}{|c|}{ Census } \\
\hline & Plants & Sales & Employment \\
\hline Wholesale & 431,013 & 4,570 & 5,830 \\
\hline Manufacturing & 348,813 & 3,900 & 14,600 \\
\hline Total & 779,826 & 8,470 & 20,430 \\
\hline
\end{tabular}

Note: FGP Status: Yes indicates the establishment performed design or engineering activity in product development and did manufacturing at the plant or purchased contract manufacturing services; No indicates the plant did no design or engineering activity in product development and/or was not involved in manufacturing either at the plant or through the purchase of contract manufacturing services. In 2002, only plants in the Census of Wholesale Trade were asked the design question. Census: Manufacturing indicates the plant was covered by the Census of Manufactures; Wholesale indicates the plant was covered by the Census of Wholesale Trade. The numbers in the cells represent the sums within the category. Employment is in thousands of workers, Sales are in billions of 2002 dollars. 
Table 4: Plants, Sales and Employment by FGP Status and Census, 2007

\begin{tabular}{|c|c|c|c|c|}
\hline \multicolumn{5}{|c|}{ FGP Status } \\
\hline & & Plants & Sales & Employment \\
\hline \multirow{2}{*}{ Wholesale } & No & 142,961 & 2,600 & 2,487 \\
\hline & Yes & 16,752 & 279 & 431 \\
\hline \multirow{3}{*}{ Manufacturing } & No & 43,676 & 1,360 & 3,024 \\
\hline & Yes & 61,427 & 2,520 & 6,031 \\
\hline & Total & 264,816 & 6,750 & 11,973 \\
\hline \multicolumn{5}{|c|}{ Census } \\
\hline & & Plants & Sales & Employment \\
\hline \multirow{2}{*}{\multicolumn{2}{|c|}{$\begin{array}{c}\text { Wholesale } \\
\text { Manufacturing }\end{array}$}} & 434,984 & 6,520 & 6,230 \\
\hline & & 332,536 & 5,320 & 13,400 \\
\hline \multicolumn{2}{|c|}{ Total } & 767,520 & 11,840 & 19,630 \\
\hline
\end{tabular}

Note: FGP Status: Yes indicates that the plant did design and the primary activity was Manufacturing, Contracting, or Other, or that the plant did design and the primary activity was Resales and the plant purchased contract manufacturing services; No indicates that the plant did not design or that the plant did design and the primary activity was Resales and the plant did not purchase contract manufacturing services. Plants in both the Census of Manufactures and the Census of Wholesale Trade were asked the design, primary activity and contract manufacturing questions - for the exact coverage see the Data Appendix. Census: Manufacturing indicates the plant was covered by the Census of Manufactures; Wholesale indicates the plant was covered by the Census of Wholesale Trade. The numbers in the cells represent the sums within the category. Employment is in thousands of workers, Sales are in billions of 2007 dollars. 
Table 5: Plant Characteristics by FGP Status and Census, 2002

\begin{tabular}{|c|c|c|c|c|c|}
\hline \multicolumn{6}{|c|}{ FGP Status } \\
\hline & Sales & Employment & $\log \mathrm{VA} /$ worker & Age & Wage \\
\hline No & 15,136 & 16.0 & 4.81 & 12.2 & 39.9 \\
\hline Yes & 8,918 & 21.0 & 4.47 & 11.6 & 39.9 \\
\hline Total & 14,297 & 16.6 & 4.77 & 12.1 & 39.9 \\
\hline & \multicolumn{5}{|c|}{ Relative to NAICS 6-digit industry means } \\
\hline & Sales & Employment & $\log \mathrm{VA} /$ worker & Age & Wage \\
\hline No & 1.29 & 1.15 & 0.155 & 1.11 & 1.06 \\
\hline Yes & 1.23 & 1.67 & 0.010 & 1.11 & 1.07 \\
\hline Total & 1.28 & 1.22 & 0.136 & 1.11 & 1.06 \\
\hline \multicolumn{6}{|c|}{ Census } \\
\hline & Sales & Employment & $\log \mathrm{VA} /$ worker & Age & Wage \\
\hline Wholesale & 10,600 & 13.5 & 4.55 & 10.8 & 37.1 \\
\hline Manufacturing & 11,173 & 41.9 & 4.16 & 13.0 & 29.7 \\
\hline Total & 10,856 & 26.2 & 4.37 & 11.8 & 33.6 \\
\hline
\end{tabular}

Note: FGP Status: Yes indicates the establishment performed design or engineering activity in product development (row 1 of Table1) and did manufacturing at the plant or purchased contract manufacturing services (columns 2 or 3 of Table1); No indicates the plant did no design or engineering activity in product development and/or was not involved in manufacturing either at the plant or through the purchase of contract manufacturing services. Plants in both the 2007 Census of Manufactures and the 2007 Census of Wholesale Trade were asked the design, primary activity and contract manufacturing questions for the exact coverage see the Data Appendix. Census: Manufacturing indicates the plant was covered by the Census of Manufactures; Wholesale indicates the plant was covered by the Census of Wholesale Trade. The numbers in the cells represent the sums within the category. Sales and Wage are in '000s of 2002 dollars. 
Table 6: Plant Characteristics by FGP Status and Census, 2007

\begin{tabular}{|c|c|c|c|c|c|c|}
\hline \multicolumn{7}{|c|}{ FGP Status } \\
\hline & & Sales & Employment & $\log$ VA/worker & Age & Wage \\
\hline \multirow{2}{*}{ Wholesale } & No & 18,189 & 17.4 & 4.79 & 14.0 & 44.6 \\
\hline & Yes & 16,667 & 25.7 & 4.78 & 12.9 & 49.4 \\
\hline \multirow{5}{*}{ Manufacturing } & No & 40,959 & 98.2 & 4.59 & 19.1 & 41.9 \\
\hline & Yes & 31,111 & 69.2 & 4.52 & 17.9 & 39.0 \\
\hline & Total & 25,506 & 45.2 & 4.70 & 15.8 & 43.3 \\
\hline & & & lative to NAI & S 6-digit industr & mea & \\
\hline & & Sales & Employment & log VA/worker & Age & Wage \\
\hline \multirow{2}{*}{ Wholesale } & No & 1.11 & 1.06 & 0.126 & 1.12 & 1.05 \\
\hline & Yes & 1.31 & 1.65 & 0.154 & 1.10 & 1.13 \\
\hline \multirow{3}{*}{ Manufacturing } & No & 2.26 & 2.15 & 0.016 & 1.25 & 1.12 \\
\hline & Yes & 1.78 & 1.72 & -0.004 & 1.17 & 1.09 \\
\hline & Total & 1.50 & 1.46 & 0.081 & 1.16 & 1.08 \\
\hline \multicolumn{7}{|c|}{ Census } \\
\hline & & Sales & Employment & log VA/worker & Age & Wage \\
\hline \multirow{3}{*}{\multicolumn{2}{|c|}{$\begin{array}{c}\text { Wholesale } \\
\text { Manufacturing } \\
\text { Total }\end{array}$}} & 14,979 & 14.3 & 4.79 & 12.1 & 43.4 \\
\hline & & 15,997 & 40.3 & 4.48 & 14.7 & 34.9 \\
\hline & & 15,420 & 25.6 & 4.66 & 13.2 & 39.6 \\
\hline
\end{tabular}

Note: FGP Status: Yes indicates that the plant did design and the primary activity was Manufacturing, Contracting, or Other, or that the plant did design and the primary activity was Resales and the plant purchased contract manufacturing services; No indicates that the plant did not design or that the plant did design and the primary activity was Resales and the plant did not purchase contract manufacturing services. Census: Manufacturing indicates the plant was covered by the Census of Manufactures; Wholesale indicates the plant was covered by the Census of Wholesale Trade. Sales and Wage are in '000s of 2007 dollars. 
Table 7: Firm Counts by FGPF Status, 2002 and 2007

\begin{tabular}{|l|c|crr|r|}
\hline & \multicolumn{5}{|c|}{ Firm Type - 2002 } \\
\hline \multirow{1}{*}{ FGPF Status } & Manufacturing & Mixed & Wholesale & Total \\
\cline { 2 - 6 } & Missing & 298,025 & 1,894 & 185,484 & 485,403 \\
& No & - & 2,612 & 125,732 & 128,344 \\
& Yes & - & 961 & 24,388 & 25,349 \\
\cline { 2 - 6 } & Total & 298,025 & 5,467 & 335,604 & 639,096 \\
\cline { 2 - 6 } & \multicolumn{5}{|c|}{} \\
\cline { 2 - 6 } & Missing & 282,020 & 2,654 & 213,871 & 498,545 \\
& No & - & 2,152 & 100,883 & 103,035 \\
& Yes & - & 757 & 13,505 & 14,262 \\
\cline { 2 - 6 } & Total & 282,020 & 5,563 & 328,259 & 615,842 \\
\hline
\end{tabular}

Note: Firm Type: Manufacturing indicates firms with no wholesale plants; Mixed indicates firms with both manufacturing and wholesale plants; Wholesale indicates firms with only wholesale plants. FGPF Status: Missing indicates firms with no FGP wholesale plants and at least one wholesale plant with missing FGP status; No indicates firms with no FGP wholesale plants and no wholesale plants with missing FGP status; Yes indicates firms with at least one FGP wholesale plant. 


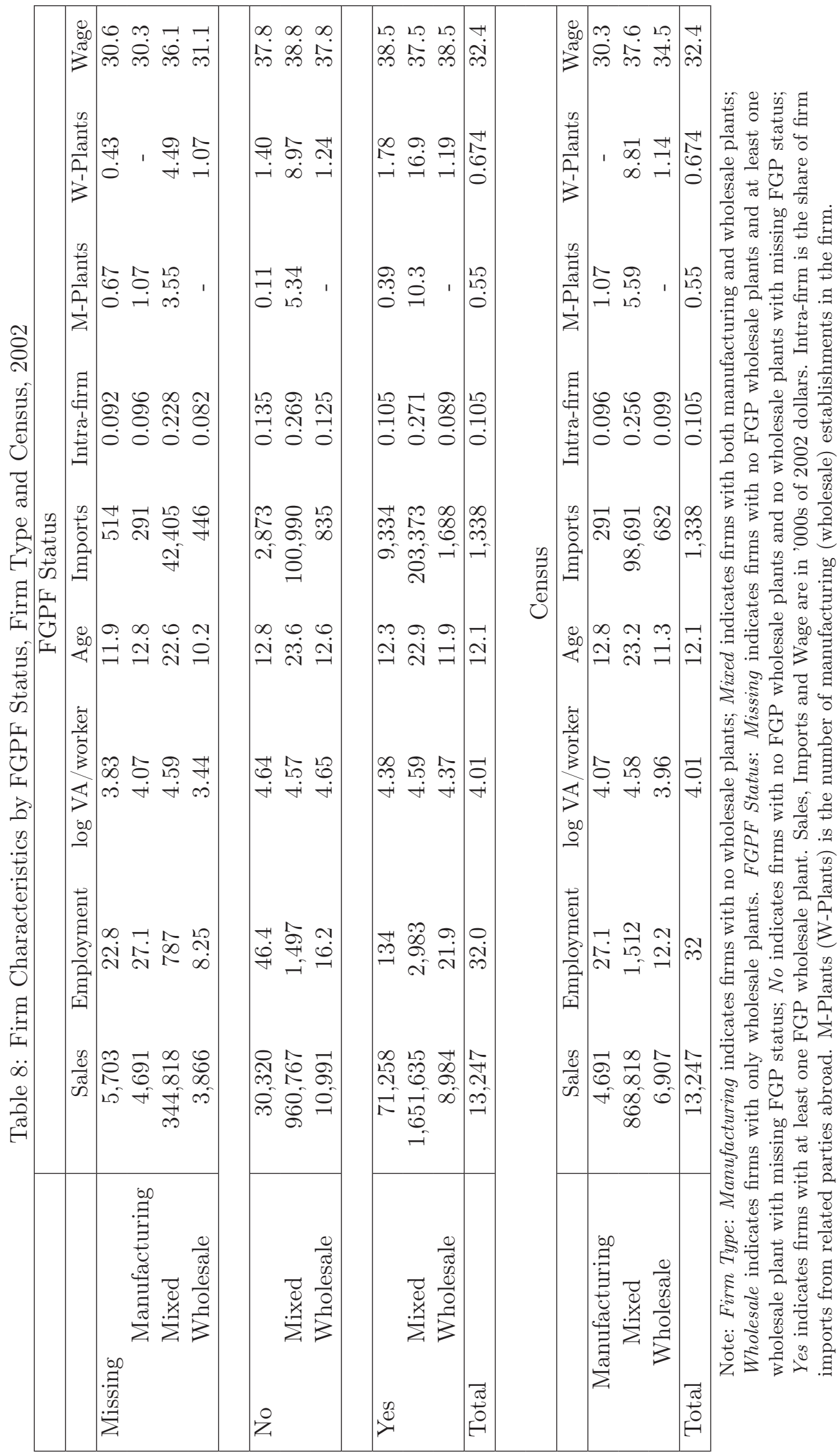




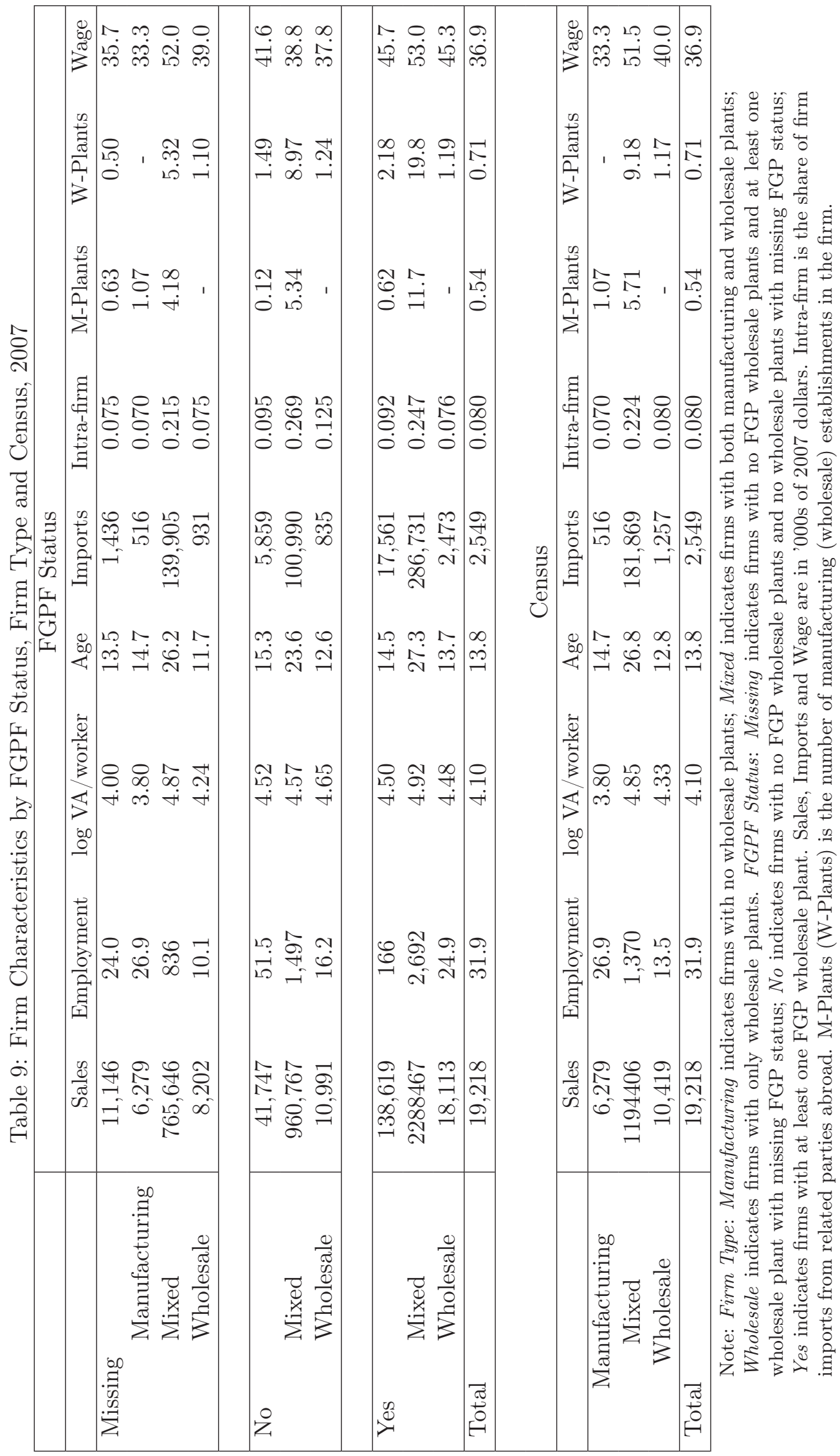

